Shcherbakov A. V., Kolarov G. I.

Щербаков А. В., Коларов Г. И.

\title{
FOREIGN EXPERIENCE IN ENSURING PENITENTIARY SECURITY
}

\section{ЗАРУБЕЖНЫЙ ОПЫТ ОБЕСПЕЧЕНИЯ ПЕНИТЕНЦИАРНОЙ БЕЗОПАСНОСТИ}

\begin{abstract}
The article constructively examines the activities of penitentiary institutions of leading foreign countries to ensure penitentiary security, taking into account the possibility of its use in domestic practice. The general characteristic of the modern Penal system of Russia is given, the main stages of its reform are noted, the political line of humanization of the Penal sphere while ensuring security for society, citizens and the state is pointed out. The internal and external aspects of penitentiary security, their organic interrelation and its integral and complex character are noted. On the basis of comparative legal method, in combination with other methods of scientific knowledge, the foreign experience of ensuring security of penitentiary institutions by differentiating convicts and conditions of serving sentences, as well as taking into account the wide use of advanced technical means of control and supervision in the process of penitentiary activity, is considered. As a result of generalization of foreign experience and its comparison with domestic practice, the existing problems of legal regulation in terms of differentiation of convicts serving sentences with isolation from society, as well as in the use of technical means to ensure prison security, are identified, and amendments to the current Penal legislation are proposed. As a matter of discussion, taking into account the review of best foreign experience, issues relevant to domestic practice, concerning the peculiarities of ensuring prison security in emergency situations, the model of a private prison institution, and the development of forms of social control and supervision of persons released from prison institutions, are noted. In this regard, conclusions about the parameters of foreign experience use in domestic practice are formulated.
\end{abstract}

Keywords: Penal system, penitentiary security, Russia, foreign experience.

Аннотация. В статье конструктивно изучается деятельность пенитенциарных учреждений ведущих иностранных государств по обеспечению пенитенциарной безопасности, с учетом возможности ее использования в отечественной практике. Дана общая характеристика современной уголовно-исполнительной системы России, выделены основные этапы ее реформирования, указано на политическую

(C) Shcherbakov A. V., Kolarov G. I., 2019

() Щербаков А. В., Коларов Г. И., 2019 
линию гуманизации уголовно-исполнительной сферы при обеспечении безопасности для общества, граждан и государства. Выделены внутрисистемная и внешняя стороны пенитенциарной безопасности, отмечена их органичная взаимосвязь и ее целостный, комплексный характер. На базе сравнительно-правового метода, в сочетании с другими методами научного познания, рассмотрен зарубежный опыт обеспечения безопасности пенитенциарных учреждений посредством дифференциации осужденных и условий отбывания наказаний, а также с учетом широкого использования передовых технических средств контроля и надзора в процессе пенитенциарной деятельности. В результате обобщения зарубежного опыта и его сопоставления с отечественной практикой, выявлены существующие в настоящий момент проблемы правового регулирования в части дифференциации осужденных, отбывающих наказания с изоляцией от общества, а также в вопросе применения технических средств обеспечения пенитенциарной безопасности, предложены коррективы в действующее уголовно-исполнительное законодательство. В порядке обсуждения, с учетом обзора передового зарубежного опыта выделены актуальные для отечественной практики вопросы, касающиеся особенностей обеспечения пенитенциарной безопасности в условиях чрезвычайных ситуаций, модели частного пенитенциарного учреждения, развития форм социального контроля и надзора за лицами, освобожденными из пенитенциарных учреждений. В связи с этим сформулированы выводы о параметрах восприятия зарубежного опыта в отечественной практике.

Ключевые слова: уголовно-исполнительная система, пенитенциарная безопасность, Россия, зарубежный опыт.

\section{Information about authors / Сведения об авторах}

Andrey Vasil'evich Shcherbakov, PhD (Law), Associate Professor, head of the department of organization of the regime and operational search activity in the Penal system, Academy of the FPS of Russia (Pskov branch), Pskov, Russian Federation, e-mail: andrey-sherbakov-1973@yandex.ru.

Андрей Васильевич Щербаков, кандидат юридических наук, доцент, начальник кафедры организации режима и оперативно-розыскной деятельности в уголовно-исполнительной системе Псковкого филиала, Академия ФСИН России, г. Псков, Российская Федерация, e-mail: andrey-sherbakov-1973@yandex.ru.

Georgiy Ivanovich Kolarov, DSc (Political science), lecturer, Varna University of Economics, Varna, Republic of Bulgaria, e-mail: gikolarov@yandex.ru.

Георгий Иванович Коларов, доктор политологии, преподаватель, Экономический университет Варны, г. Варны, Республика Болгария, e-mail: gikolarov@yandex.ru.

\section{Recommended citation / Для цитирования}

Shcherbakov, A. V. \& Kolarov, G. I. 2019, 'Foreign experience in ensuring penitentiary security', International penitentiary journal, vol. 1(1-3), iss. 3, pp. 166-190, doi: 10.33463/2712-7737.2019.01(1-3).3.166-190. 
International penitentiary journal, 2019, vol. 1(1-3), iss. 3 SUBJECT DISCUSSIONS / ДИСКУССИИ

Щербаков, А. В. Зарубежный опыт обеспечения пенитенциарной безопасности / А. В. Щербаков, Г. И. Коларов // Международный пенитенциарный журнал. 2019. - T. 1(1-3), № 3. - С. 166-190. - DOI : 10.33463/2712-7737.2019.01(1-3).3.166-190. 


\section{Introduction}

The fundamental transformations, carried out in Russia, aimed at modernizing and, at the same time, developing the Russian State and society; they are comprehensive and affect, among other things, the relations that arise and develop in the penitentiary sphere, including issues of penitentiary security. The Russian Federation proceeds from the need to constantly improve the system of ensuring public security; in this regard, the tasks and organizational and legal tools for creating a stable basis for increasing the economic, political, military and spiritual potential of the Russian Federation and increasing its role in the emerging polycentric world are now conceptually defined.

State policy in the sphere of national security and socio-economic development of the Russian Federation contributes to the implementation of strategic national priorities and effective protection of national interests. It should be noted that, firstly, penitentiary security genetically related to the overall system of national security, because it includes a set of legal and organizational forces and means aimed at countering threats to the normal development of the Russian state and society, and protecting the interests of citizens. Secondly, penitentiary security contains a significant specificity due to the peculiarities of its main threats (crime, criminal and prison subculture, penitentiary recidivism) and manifests itself in the organizational and legal tools to ensure it (Bykov, A. V. 2017, p. 57; Romashov, R. A. \& Tonkov, E. N. 2014, pp. 266-267).

Penitentiary security is both intra-system and inter-system in nature, since intra-system threats cause danger to persons directly in the penitentiary environment, especially convicts and prison staff. In the field of inter-system relations, the penitentiary system itself should be considered as a source of penitentiary danger, whose activities constitute a certain threat to a «law-abiding» society. Thus, a legitimate question is about the two main and organically interrelated areas of prison security: internal security as a system of means and methods of providing effective anti-malware threats in relation to the convicts and employees of penal institutions; external security as a system of means and methods to counteract threats coming from the prison system itself (Romashov, R. A. \& Tonkov, E. N. 2014, pp. 266-267).

In the case of Russia, the special role of the Penal system in ensuring penitentiary security should be discussed. It should be explained that the term «the Penal system» is traditionally used in the Russian literature in the sense of a state-legal nature and appropriately organized institution intended for activities implementation in the field of criminal penalties execution, and performing in this regard significant functions for the state and society (Lelyukh, V. F. 2006; Smirnov, L. B. 2007). In turn, the dynamics of state-legal and social transformations is manifested in changes in the content of functions, specific tasks of the Penal system and its constituent bodies and institutions. For example, in the Russian Empire, the development and acculturation of new lands was carried out with the help of convicts (Smirnov, L. B. 2007, pp. 30, 33), in the USSR the GULAG was a powerful industrial and economic complex that took part in all large-scale projects of Soviet construction (Smirnov, L. B. 2007, pp. 57, 59-60). In modern conditions, the penal policy is undergoing radical changes. In connection with the establishment in modern Russia at the constitutional level of the provision on the recognition of a person, his rights and freedoms as the highest value (Article 2 of the Constitution of the Russian Federation), active and versatile participation of Russia in integration processes in the field of crime prevention, combating it and treatment of offenders has led to humanization of the Penal system, a revision of the priorities of its activities; the penitentiary direction is gradually replacing the punitive and its derivatives. It should be noted that the idea of humanizing the domestic Penal system in understanding 
of its complex and integral nature was first voiced in the USSR in the Concept of reforming the Penal system, approved by the Board of the Ministry of Internal Affairs of the USSR in 1990 (Smirnov, L. B. 2007, pp. 66-67). At the same time, certain aspects of the penal sphere humanization were previously reflected in the works of domestic authors (Poznyshev, S. V. 1923; Belyaev, N. A. 1963).

The organizational structure of the modern Penal system of Russia is two-level and includes: the Federal penitentiary service of Russia and its subordinate territorial authorities in the subjects of the Russian Federation, which manage penitentiary institutions located on the territory of the relevant subject, in accordance with the Federal Penal legislation; according to the decision of the Government of the Russian Federation, the Penal system may include pretrial detention centers, enterprises specially created to support activities of this system, research, design, medical, educational and other organizations in connection with their participation in penitentiary activities implementation (its separate directions).

The main milestones that mark the process of humanization of the Penal system of Russia, observed in the modern period, include:

- adoption of laws in the sphere of organization and activity of the Penal system that take into account constitutional provisions and international standards in the penitentiary sphere (Law of the Russian Federation No. 5473-1 «On institutions and bodies executing criminal penalties in the form of deprivation of liberty» (adopted on 21.07.1993); Penal code of the Russian Federation of 1997);

- transferring of the Russian Penal system from the Ministry of Internal Affairs to the Ministry of Justice of the Russian Federation in 1997 (based on the Decree of the President of the Russian Federation adopted on 8.10.1997);

- formation of the Federal penitentiary service in 2004, which was given the functions of the Ministry of Justice of the Russian Federation to ensure the execution of criminal penalties, taking into account the update of legislation and Russia's international obligations in the penitentiary sphere (based on the Decree of the President of the Russian Federation on 09.04. 2004);

- development, adoption and implementation of measures to implement the Concept of the Russian Penal system development until 2020 (approved by the Order of the Government of the Russian Federation No. 1772-R on 14.10.2010), where the general characteristics and current state of the Penal system, the main directions, forms and methods of improvement of the Penal system, taking into account international standards and requirements of social development, the goals and objectives related to the further humanization of penal sphere and raising the effectiveness of management of the Penal system, including through the introduction of modern technologies and technical means in the practice of punishments execution.

It is significant that the development of international cooperation with the penitentiary systems of foreign States, international bodies and non-governmental organizations is noted among these tasks. This direction is implemented in conjunction with Russia's international legal obligations arising from participation in universal (UN) and regional (in particular, the Council of Europe) international organizations.

The process of humanization of the Russian criminal Executive system is characterized by a reduction in the number of convicts serving sentences of imprisonment, and the search for alternatives to criminal penalties connected with isolation from society. Thus, for comparison, if in 2002 the number of convicts in correctional institutions located on the territory of Russia (places of deprivation of liberty) were 877,393 thousand people, in 2015-656,618 thousand people (Gorban', D. V. 2016, pp. 176-183). At the same time, the practice of assigning and executing alternative types of punishment is expanding. Currently, the system of criminal penalties provided for by the current Criminal code of the Russian Federation (Chapter 9) 
is built on the principle of less severe, and, accordingly, not related to isolation from society (in particular, fines, correctional labor, forced labor) to more severe forms of criminal legal impact (imprisonment).

At the same time, the Penal inspections in Russia have to control sentences execution of increasing recidivist contingent, which, in turn, complicates their work and reduces its effectiveness (Degtyareva, O. L. 2015, pp. 3-6). Currently there is also rejuvenation and deterioration of criminological characteristics among convicts serving sentences with isolation from society in prisons of Russia, increasing the number of prisoners who are prone to various forms of destructive behavior, intensification of criminal leaders attempting to coordinate illegal actions of convicts (many of which dealt with organized crime), including disorganization of prisons and also attacks on employees of the Penal system (Kudryavtsev, A. V. 2013, pp. 20-23).

In general, the Russian Penal system is going through a complicated process interconnected with the movement of Russian society and the state and international cooperation in this area. Finally, another problem is in the fact that currently in Russia at the level of individual and collective consciousness, the prison environment is associated with hostile, which entails an absolute priority in tools for penitentiary security with measures of a forceful nature, implemented within the framework of conflict relations. Meanwhile, transition to the paradigm of civilizational culture in the context of prison security involves the implementation in practice of the Penal system of innovative tools and methods of social partnership, providing a combination of incentives that encourage the convicted person to correction with the use of effective means to prevent penitentiary crimes and its negative processes and phenomena (Romashov, R. A. \& Tonkov, E. N. 2014, pp. 266-267).

In connection with these circumstances, the problem of studying the best foreign experience in ensuring penitentiary security and the parameters of its use in the Penal system of Russia in modern conditions of functioning and development is updated. The purpose of this study is to identify positive elements of foreign experience in ensuring penitentiary security and prospects for its use in the course of the ongoing reform of the Russian Penal system in modern conditions.

The problem of ensuring penitentiary security is reflected in the scientific works of lawyers and representatives of other branches of scientific knowledge. The theoretical foundations of public security, an integral part of which is penitentiary security, were developed in the research of A. A. Ter-Akopov (1998), A. B. Antonov and V. G. Balashov (1996), M. M. Babayev and E. N. Rakhmanova (2003). In the context of the broader issue of safety, security and protection of individuals, society and the state from crime and its criminal criminogenic threats G. G. Gorshenkov (2009) substantiates the concept of anti-criminal security of the person, as well as the provisions of the state policy of ensuring anti-criminal security of the individual, a number of practical proposals and recommendations in this part. In the study of theoretical and methodological problems of cognition and prevention of the crime, conducted by I. V. Shalakhin (2011), a separate section is devoted to the promotion of criminological security of the person, where in conjunction with the main directions of anticriminal policy sets strategic priorities and corresponding blocks of organizational and legal measures of criminological security for citizens: preventing (reducing the level of) criminal infection of citizens; minimizing the risk of becoming a victim of a crime (suicide associated with the action of criminal and criminogenic factors); restoring the person affected by crime. Among the works of foreign authors, we point to the study of the famous criminologist Michael Tonry (USA) (2001), who indicated the special importance of the model for building criminal justice, which assumes the priority of measures aimed at ensuring the safety of society, protecting it from crime. 
Some authors address directly the problem of penitentiary security, its theoretical and applied aspects. In particular, B.B. Kazak (2002) in the monographic study paid attention to domestic and foreign penal theories and security models, identified system of safety factors in the Penal system, outlined the main components of security control in the prison system, described the main means of convicts' correction in the context of prison security (regime, socially useful work, educational training and professional training of convicts, social and educational work with them). In the monographic study of V. F. Chornyy (1996) was the systematization of negative factors affecting the security status of convicts in places of liberty deprivation; he determined value, nature and content of prisoners' security as an important element in the mechanism of ensuring and protection of their rights and legitimate interests; the classification of legal norms regulating the security of convicts in penal institutions. R. Z. Useev devotes his research to the difficult and at the same time theoretically and practically significant issue of defining the paradigm of penitentiary security for the modern Russian Penal system. Based on the generalization of scientific and empirical material, he came to conclusions about the complex nature of penitentiary dangers and security of the Penal system, and the need for a conceptual definition of this concept at the legislative level (Useev, R. Z. 2015, pp. 56-61). Taking into account modern realities, A. F. Galuzin (2015) conducts a study of the penitentiary security of the Penal system, considering it in the context of the penitentiary function carried out by the state with the active participation of civil society; identifies and classifies the main sources of penitentiary dangers; notes the internal contradictory and conflicting unity of the penitentiary environment; characterizes measures to ensure internal and external penitentiary security, and concludes that, in fact, ensuring penitentiary security embodies humanism in the penitentiary sphere. The study of N. N. Kutakov (2014) is devoted to the organizational and legal basis for ensuring safety of correctional personnel in Russia. It contains conclusions about determinants that affect safety of correctional personnel, justifies the author's methodology for evaluating the effectiveness of activities to ensure this safety, and proposes changes and additions to the legislation in force in the field of criminal penalties execution related to isolation from society.

Recognizing the theoretical and practical significance of these studies, it should be noted that they do not specifically point out the possibility of perceiving positive foreign experience in ensuring penitentiary security.

It should also be noted that foreign experience in the organization and functioning of penitentiary systems and ensuring penitentiary security in them is provided in a number of studies by domestic and foreign authors. In particular, an overview of the structure of penitentiary institutions of the prison type in a number of European countries, the order and conditions of serving sentences in them related to isolation from society, is given in the book of L. F. Pertli, A. M. Fumm, Yu. Yu. Zheleznaya and T. V. Borisova (2012); the authors conclude that in the light of implementation of the Concept of the Russian Penal system development until 2020, the experience of European prisons can be applied in Russia in new types of correctional institutions. A fairly detailed review of the sphere of punishments execution in foreign countries (not only European, but also located in South-East Asia) is given in the works of V. A. Zhabskiy, A. I. Kochkarev, A. S. Rudenko (2013). The authors also make judgments about the possibility of perceiving certain elements of foreign experience in the course of the Russian Penal system reforming. The analysis of foreign experience in organizational and managerial activities of penitentiary systems of the member States of the Council of Europe is carried out in the work of A. V. Bykov (2017). In the scientific work of Swiss lawyers Marcelo F. Aebi, Christine Burkhardt, Rok Hacin, Mélanie M. Tiago (2016) a comparative legal analysis 
of current trends and prospects for organizing the execution of prison sentences in Slovenia and other European countries from 2005 to 2014 was carried out. The authors note that despite the recent increase in the number of prisoners, Slovenia still has one of the lowest rates in Europe in this part and attribute this to the length of imprisonment. In addition, they analyze the structure of the Slovenian prison population, consider the correlation of legislative changes with the solution of problems of prison overcrowding, conflicts in penitentiary institutions, and summarize that, in general, the criminal law and penitentiary systems of Slovenia are more similar to their counterparts in Western Europe than in Central and Eastern Europe (Aebi, M. F., Burkhardt, C., Hacin, R. \& Tiago, M. M. 2016, pp. 430-442). The analysis of foreign experience of penitentiary activity and research in this area was carried out by P. V. Golodov and B. A. Spasennikov (2015). The authors emphasize the importance of studying this experience, considering it as one of the necessary conditions for ensuring a scientific approach to the ongoing transformations of Russian penitentiary practice.

Certain aspects of penitentiary security in connection with foreign experience in ensuring it are reflected in the following publications. In the work of A.V. Bykov and M. A. Kaluzhina (2015) examines the USA penitentiary system and the main areas of security, noting that the issues of control and supervision of prisoners in the United States belong to the sphere of state interests and are considered from the standpoint of ensuring comprehensive security, the positive role of such approaches in terms of improving the efficiency of penitentiary institutions, and the expediency of taking this constructive approach when reforming the Russian Penal system. A. I. Glushkov (2013) examines the foreign practice of regulating law enforcement activities of institutions of the Penal system in case of emergency situations, at the same time, he justifies the need for the use of certain provisions of foreign normative legal acts in Russian legislation that regulate the mechanism for implementing special conditions in emergency situations in institutions of the Penal system. Foreign practice of using the electronic monitoring system of controlled entities is considered by E. A. Timofeeva and O. A. Motin (2014). At the same time, it is compared with the Russian experience that is emerging in this area. The authors conclude that the use of advanced foreign experience will help to improve the technical, organizational and legal aspects of electronic monitoring in Russia and, in addition, significantly reduce the burden on the law enforcement and judicial systems, and will reduce the number of persons serving sentences in correctional institutions. In the book of Andrew Coyle (2002) he presented his progressive vision (a recognised specialist in the field of prison activities and prison studies) in terms of prison management, when the balance of prison security and prisoners' rights, the relationship of international standards and domestic prison rules the different levels of protection of prisoners, attention to physical and procedural measures to ensure prison security are discussed. Norwegian researcher Erich Saheim (2006) examines the main issues of personnel training for correctional institutions in Norway, evaluates this process from the point of view of the European prison rules, and specifies in this regard the requirements for personnel selection in terms of work experience, ethical and professional qualities, as well as motivation. The article by V. A. Utkin (2016) analyzes changes in the penal policy, law and directions for reforming the organizational foundations of the Penal system in the context of Russia's accession to the Council of Europe, as well as taking into account the new European penitentiary rules (2006). In particular, the author points to the current trend of changing the penal paradigm, consisting in the transition from «single-mode correctional colonies» to «hybrid» correctional institutions of «multi-mode security». In the works of S. Kh. Shamsunov (2016), E. A. Timofeeva (2017) foreign experience of creation and 
functioning of private prisons is analyzed, judgments about the possibility of its selective use with careful study and consideration of the existing practice of corrections are expressed. In connection with the problem of penitentiary security (in its broad sense, covering the external aspect, the need to minimize the negative impact of the penitentiary environment on lawabiding society), E. A. Tokhova (2009) analyzes the foreign experience of social and legal control over persons released from correctional institutions, and she notes the well-established mechanism of socio-cultural resocialization of prisoners in a number of foreign countries, the valuable nature of foreign experience in social work with prisoners, penitentiary and postpenitentiary crime prevention in the course of reforming the Russian penitentiary system. Understanding of penitentiary security as a multidimensional phenomenon can be seen in the work of L. V. Brusnitsyn (2013), devoted to modern research of modern trends in victims' rights at the stage of sentences execution. The author, in conjunction with the study of advanced foreign experience, justifies the optimization of the current criminal procedure legislation in terms of giving the victim legal opportunities to influence the issue of parole of a person who previously committed a crime against this victim.

Valuable information about the structure and functioning of penitentiary systems in foreign countries, as well as reforms in the penitentiary sphere that affect, among other things, issues of penitentiary security, can be obtained from the following publications. In the work of O. G. Kovalev and M. V. Sheremet'eva (2013) the organization and current trends of the us penitentiary system, the classification of prison institutions, the institution of private prisons, the features of prison management, the gender and ethnic ratio of prisoners and staff are analyzed; the most acute problems (prison overcrowding, high recidivism, etc.) are identified and some ways to minimize them are provided. In the article of Martin Schmid and E. A. Ogrokhina (2013) the main distinctive features and principles of the modern Swiss penitentiary system are examined, at the same time, it is concluded that it is transparent and has the potential to promote social integration of convicts and, in this connection, to minimize penitentiary and post-penitentiary recidivism. In the article of O. M. Chernysheva (2012) the process of transformation of penitentiary institutions in Germany within the framework of the "federalism reform» announced in 2006, which granted the Federal lands exclusive legislative competence in the field of execution of punishments is examined. In this connection, the problems of law-making and law enforcement are noted. In the article of A. V. Serebrennikova (2013) the experience of criminal law codification in Germany is examined. The main attention is paid to the law of Bavaria on the punishment execution in the form of deprivation of liberty and measures of correction and security related to deprivation of liberty. Thus the conclusion about the importance of studying this experience in reforming the domestic penal law is made. In the article of O. R. Gulina (2012) the legal registration of German penitentiary system and regulation of punishment execution of at the Federal and regional levels are examined, at the same time, special attention is paid to execution of preventive arrest after serving the main type of punishment - Sicherheitsverwahrung, and to the correlation of this type of punishment with the legal norms of the European Convention on human rights and the Basic Law of Germany; it is concluded that the modern prison system of Germany, like Russia, is undergoing large-scale reform, taking into account the proximity of continental legal traditions, the experience of Germany could be useful and significant for Russia, especially in the field of understanding and interpreting the rights of persons in custody. In the article of A. M. Fumm (2011) the emergence and development of the English progressive prison system, as well as its current state and its significance for the reform of the Russian penitentiary system are discussed. In the article of Professor Gorazd 
Meshko and O. V. Druzhininskaya (2016) the situation in correctional institutions of Slovenia, in particular the limit of prison occupancy, based on statistical data, is analyzed; the authors identify the problems related to this, as well as financial and personnel difficulties, including those related to prison security, and suggests ways out of the current situation. In the article of M. Koski and O. V. Druzhininskaya (2015) the current state of the Finland Penal system, which was formed as a result of the reform in 2006, is examined; there is a positive trend of decreasing the level of prisoners and persons sentenced to public work, as well as the level of repeated offenses; the conclusion is made about the possibility of use of this experience in improving the Russian Penal system. In the article of T. F. Minyazeva and L. A. Bukalerova (2013) the experience of serving sentences in prisons in modern Norway is presented; the conclusion is made about the possibility of perceiving positive practices in the functioning of penitentiary systems in Norway and other Scandinavian countries in terms of humane treatment of prisoners and their resocialization.

However, we repeat: the whole issue of prison security, viewed through the prism of international experience influence on the Russian modern Penal system, parameters of use in domestic practice, in the course of the ongoing reforms in Russia, especially was not pointed out, and was not an independent object of scientific study.

\section{Methodological basis of the study}

The methodological basis of this study is a comparative legal method that focuses on the comparison of different legal systems, socio-legal categories and phenomena (Bakhin, S. V. 2003; Ivannikov, I. A. 2013). The practical significance of the comparative legal method is to recognize the objective process of convergence among various national legal systems, characteristic of the modern world, and, in particular, in matters of ensuring penitentiary security, taking into account the existing typological differences and national legal characteristics of a particular country. In this regard, a scientifically based assessment of the possibility and limits of foreign experience use in ensuring penitentiary security in the Russian Penal system is given. The comparative method is combined with other general scientific and special methods of cognition, namely:

- systemic (suggesting the need to consider penitentiary security as an integral, complex phenomenon, and its provision, respectively, as a process of prevention, detection and neutralization of threats and dangers emanating from the criminal and criminogenic penitentiary environment, in turn, correlating with intrasystem and inter-system socio-legal factors);

- formal-legal (involving the use of the conceptual and categorical apparatus of jurisprudence, reference to the rules of law and materials of law enforcement practice in the field of penitentiary activities of the studied countries);

- structural-functional (allowing to identify the aspects of prison security and the main components of its provision in relation to the functioning and development of prison systems in modern States).

The research method consists in studying and comparing the basic characteristics of penitentiary systems of modern States, in the part related to the issues of penitentiary security. At the same time, the main attention is given to the penitentiary countries of Europe and the United States, taking into account the degree of penitentiary systems' development and positive experience in ensuring penitentiary security in the context of humanization of penitentiary activities in combination with its effectiveness. In addition, the experience of providing penitentiary security (within the framework of the organization and activities of penitentiary institutions, including in emergency situations, as well as in post-penitentiary control) in some other countries is given.

The theoretical basis of the study is the above-mentioned publications, as well as other publications of domestic and foreign authors, 
which cover the organization and functioning of penitentiary systems in various modern States, and aspects of ensuring penitentiary security in them; in addition, in some cases, a comparison of domestic and foreign practices is carried out.

The legal, informational and empirical basis of the study is sources of current legislation on penitentiary activities, the practice of penitentiary activities cited in the special literature, statistical data and reference materials. In particular, based on special scientific and reference literature (Coyle, A. 1994; Aebi, M. F., Burkhardt, C., Hacin, R. \& Tiago, M. M. 2016; Bykov, A. V. 2017; Bykov, A. V. \& Kaluzhina, M. A. 2015; Pertli, L. F., Fumm, A. M., Zheleznaya, Yu. Yu. \& Borisova, T. V. 2012; Yakovlev, K. L., Yakovleva, E. I. \& Yakovleva, O. N. 2011) the article takes into account the provisions of the Code of Laws of the United States and the Official Guide of the Federal Bureau of prisons of the United States (2014), Law on prisons in Finland (2006), Law on enforcement of criminal sanctions in Slovenia (2000), the Criminal and Criminal Procedure Code of the Federal Republic of Germany (taking into account the reform that began in 2006), the Law on prisons (2009) and the Criminal Code of the French Republic, the Criminal Law of the Kingdom of Norway, etc. In the context of the topic under study, the Provisions of current Russian legislation are given: the Criminal Code (1996), the Criminal Procedure Code (2001), and the Penal Code (1997).

The comparison of foreign and Russian experience is carried out, taking into account the justified position about the existence of two main areas of penitentiary security, namely 1 ) internal security (in relation to the penitentiary institutions themselves) and 2) external (in relation to a law-abiding society). At the same time, the authors are aware of a certain proportion of the conditionality of this distinction, taking into account the noted holistic and complex nature of prison security and the organic relationship of its sides.

\section{Ensuring internal security of penitentiary institutions by differentiating of convicts}

The study of special literature, devoted to the analysis of foreign experience in execution of criminal penalties in closed penitentiary institutions, allows to speak about the variety of approaches of different countries (taking into account the ongoing criminal and penal policy, the level of crime, socio-economic indicators, technical equipment, the structure of the penitentiary system and its management, and other factors), at the same time, certain general provisions concerning the differentiation of correctional institutions and the number of convicts, serving their sentences, are observed (they are also filled with specific content, taking into account the national legal specifics). The role of differentiation of convicts and conditions for serving sentences, in ensuring internal security of penitentiary institutions, is described in detail in the following data for specific countries.

The United States, which traditionally ranks first in the international ranking for the number of prisoners, has a diversified correctional system (Kovalev, O. G. \& Sheremet'eva, M. V. 2013, pp. 19-22). Due to the dualistic model of federalism in the United States (Shumilov, V. M. 2013), legal, judicial, and penitentiary systems at the Federal level and within each individual state exist and function in parallel, however, regardless of the level of power, the activities of penitentiary institutions are based on strict compliance with the law, subordinated to the goal of internal security of the state and ensuring the effective functioning of public authorities and local self-government (Bykov, A. V. \& Kaluzhina, M. A. 2015, p. 28). It is important to note that each penitentiary institution is assigned a security level, from 1 to 4 , respectively:

- local correctional institutions have a security level of 1 or 2 , and more than half of the convicts are allowed to leave the protected area for a certain period of time without escort for employment or training in a profession; 
- prisons and other correctional facilities of the fourth and third security levels are under the jurisdiction of the States or the Federal government (however, these penitentiaries also have units with a more lenient regime corresponding to the second level (Kovalev, O. G. \& Sheremet'eva, M. V. 2013, pp. 19-20)).

The differentiation of convicts and, consequently, the question of determining the necessary level of security of the penitentiary institution is not only based on the sentence (thus, if the court sentences the perpetrator to a term of imprisonment of up to one year, the convicted person is transferred to the district investigative prison or to one of the local correctional institutions to serve the sentence), but also in relation to the work of reception centers, diagnostics and classification of prisoners (in the case of persons serving imprisonment for more than one year) (Kovalev, O. G. \& Sheremet'eva, M. V. 2013, pp. 19-20). In correctional institutions, there are various programs focused on the resocialization of the convicted person. In addition, the following facilities function in the United States:

- centers for the restitution (a «soft» alternative to imprisonment; convicts are sent there, if they committed an offense for the first time, but they are employable and mentally healthy, they do not have problems with drugs and alcohol, also by a court decision, convicts whose prison term is coming to an end can be also sent there; convicts undergo a socialization course, they are required to go to work and perform public works free of charge, they use earned money to pay for their accommodation in the center, court costs, and to compensate victims);

- involuntary treatment centers (there are people in need of treatment for alcoholism and drug addiction; the centers have educational programs and socialization programs; prisoners also receive professional training, and they are provided with qualified assistance in finding employment after their release);
- correctional camps (young healthy men, who have been sentenced for up to five years for non-violent crimes, are sent there for the first time, if they have such a desire; the convicts are involved in heavy public works, such as building roads, and are also required to complete an educational program and professional training course).

In Great Britain, due to the historical administrative division and different political status of its constituent territories, Scotland and Northern Ireland have their own systems of sentences execution, and England and Wales have a common system (England and Wales - 86230 convicts; Northern Ireland 1460 convicts, Scotland -7480 convicts). In the UK prison service, there are different categories of institutions for prisoners: men's and women's prisons, institutions for young offenders, institutions for juveniles, local prisons, prisons for persons with life sentences or life imprisonment centers, separately, there are so-called «Rasseivateli» (used for prisoners with the necessary high level of protection and especially dangerous criminals) (Yakovleva, E. I. \& Yakovleva, O. N. 2011, pp. 142-143). There are four placement modes for adult men: category A prisons (highest security level); category $B$ prisons (high security level); category $C$ prisons (medium security level); and category $\mathrm{D}$ prisons (open mode). In the process of serving their sentences, many prisoners are placed in a lower security category, in accordance with the decision of the prison administration, which is based on an assessment of the convict's personality and behavior, and some prisoners are placed in a higher risk category than previously assumed (Yakovleva, E. I. \& Yakovleva, O. N. 2011, p. 143). This approach to convicts' separation can be used in domestic practice, while taking into account the existing typological differences between the legal systems of Russia and Great Britain (in particular, the lack of codified legislation in the UK in the area of appointment and execution of criminal penalties). 
In Germany (64 thousand 193 convicts) (Bykov, A. V. 2017) the execution of a sentence of imprisonment is carried out in open and closed penitentiary institutions (the latter prevail). Prisoners are sent to penitentiary institutions in different degrees of isolation, depending on the danger of their personality. It should be noted that in Germany, in conjunction with the ongoing reform (since 2006), execution of sentences is regulated by the legislation of the Federal States, it, however, does not change the main goals and principles of the organization of sentences execution, relating to protection of society from crime and resocialization of convicted persons.

In France, penitentiary institutions are divided into: detention houses (where people who are arrested are placed, as well as those who are sentenced to imprisonment for less than one year); Central prisons ( 5 prisons, one of which is women's, where the most dangerous convicts are held with a much stricter regime of detention and increased security measures); detention centers that are designed for convicts who, in the opinion of the administration, have the best chance of re-adaptation (where the detention regime is focused on the maximum possible communication of convicts with the outside world); penitentiary centers (mixed-type institutions that may have adjacent departments for both persons under investigation and convicts); semi-free autonomous centers (placed convicts have no more than one year left to serve and have reached a certain degree of correction) (Yakovleva, E. I. \& Yakovleva, O. N. 2011, p. 150).

In Spain (as in Portugal), there are four categories of convict detention (closed, semi-open, open (overnight stay) and parole under house arrest), which can be applied by transferring from one correctional institution to another (so-called progressive punishment system) (Teplyashin, P. V. 2016, pp. 113-120).

In Finland, there are also different types of punishment regime related to isolation from society, taking into account the behavior of the convicted person, indicating his correction, there are rules for transferring from a more strict to a less strict regime of detention (Tokhova, E. A. 2009, pp. 198-201). The distribution of places in correctional institutions in Finland is such that $69 \%$ are in closed prisons and $31 \%$ are in open prisons and prison cells. At the same time, prisoners who are able to adapt to conditions that are freer than those in closed prisons are placed in open prisons, and any convicted person is transferred to an open prison at the end of the sentence (Koski, M. \& Druzhiniskaya, O. V. 2015, p. 92).

Slovenia has one of the lowest prison population levels (63 prisoners per 100,000 inhabitants), and at the same time there is a problem of overcrowding in prisons; determining a correctional facility for persons sentenced to deprivation of liberty, the security level and regime of the correctional facility (closed, semi-open and open institutions or blocks in a correctional facility) are also taken into account (along with sex, sentence, age of prisoners) (Meshko, G. \& Druzhininskaya, O. V. 2016, p. 66).

In Norway (crime rates and prison rates are significantly lower than in other European countries; the prison population is 3,000 prisoners) convicts are placed in prisons with different levels of security based on individual risk and needs assessments, taking into account, among other factors, the impact of criminal environment on low-risk prisoners, as well as the importance of social rehabilitation work (Minyazeva, T. F. \& Bukalerova, L. A. 2013 , p. 88). The progressive system of punishment execution by means of differentiation of social elevators is consistently implemented in the Norwegian penitentiary system: convicts, depending on their motivations, serve their sentences on different floors and in different departments of the prison, which differ in their conditions of detention.

With regard to foreign experience outside the United States and European countries, there is an example of New Zealand, which ranks the third place in the international ranking in terms of imprisonment level. In New Zealand, 
prisoners convicted for serious and especially grave crimes are placed in a high-security unit, where there is a clear division of prisoners into categories (Kurkina, I. N. 2013, p. 146). Along with completely closed correctional institutions in this country, there are open-type prisons (analogs of Russian colonies-settlements), where convicts are transferred for exemplary behavior (Bagreeva, E. G. 2012, pp. 21-24).

In Russia, institutions of the Penal system, that carry out sentences of imprisonment, include: colonies-settlement (convicts serving sentences primarily for careless crimes, in addition, for the first time convicted of minor crimes); educational colonies for juveniles; medical correctional institutions; correctional colonies of general, strict or special regime (the regime is determined taking into account the severity of the crime, as well as recidivism); prisons (their number is small, they contain persons who have committed especially grave crime, with a particularly dangerous recidivism, as well as transferred from correctional colonies on a court sentence in connection with a malicious violation of the order during serving a sentence) (Article 16, 74 of the Penal Code of the Russian Federation). At the same time, the domestic Penal legislation contains provisions on the separate detention of men and women convicted for committing crimes, first-time offenders and those convicts, who previously served a sentence of imprisonment (Article 80 of the Penal Code of the Russian Federation), as well as provisions on changing the type of correctional institution for positively characterized convicts (Article 78 of the Penal Code of the Russian Federation).

At the same time, it is obvious that there is potential for improving legislative provisions and practices, taking into account the positive foreign experience of differentiating the conditions of detention for persons sentenced to imprisonment. Taking into account the above examples, we are talking about two promising areas:

- differentiation of convicts based on the conclusions of specialized centers (which, obviously, should include psychologists, sociologists, lawyers and representatives of other areas related to the study of the penitentiary system and its security) about the level of their danger and taken in conjunction with this decision to send a person (in some cases, also taking into account his consent) to the appropriate penitentiary institution (where there is a corresponding socialization program);

- possibility of transferring a convicted person, whose term of imprisonment is ending, to a penitentiary institution with a more «soft regime» with the simultaneous passage of appropriate adaptation and resocialization programs.

These provisions aimed at ensuring penitentiary security in the parameters of the adopted political line for the humanization of the Penal system of Russia should be reflected in the domestic Penal legislation, specifically, in Article 78 (Changing the type of correctional institution) and in Article 87 (Conditions for serving sentences by convicted persons to imprisonment) of the Penal Code of the Russian Federation.

\section{Technical component of penitentiary security}

In the context of ensuring the security of penitentiary institutions, the important role of the technical component should be pointed out (this applies primarily to economically developed countries). For example, in the Netherlands, places of detention are equipped with video cameras that constantly monitor prisoners (prisoners have almost no personal space, except for a toilet and shower) (Kurkina, I. N. 2013, p. 146).

In Spain, the security system of penitentiary institutions (including the means of its technical support) correlates with the type of institution. At the same time, social integration centers that are not closed and operate on the basis of the principle of trust in convicts (the latter have the opportunity to work and undergo treatment outside of these institutions) have an effective 
security system that allows to control convicts using electronic GPS monitoring bracelets, blood alcohol indicators, and personal voice detectors (Teplyashin, P. V. 2016, pp. 113-120).

The most advanced system of technical equipment for prison security exists in the United States, where:

- an important tool for the implementation of operational control of the criminal environment is centralized record, which allows to collect, accumulate, store, systematize and issue operational information (informational analytical automated program for monitoring the behavior of individuals and criminal communities; the main objects of accounting are prisoners with high criminal activity, manifesting themselves in violation of the order of serving a sentence and supporting persons who violate it, having stable links with criminally active persons outside, and so on.);

- a modern method of optimizing the implementation of control and supervision, increasing the level of ensuring the order and conditions of execution and serving a sentence in the form of imprisonment is the possibility of using technical and special means (including the latest audio-visual, electronic and other technical achievements), in particular, to prevent escapes and other crimes, violations of the established procedure for serving sentences, as well as to obtain the necessary information about the behavior of convicts (Bykov, A. V. \& Kaluzhina, M. A. 2015, pp. 28-32).

In general, the use of computer technologies with the use of digital control and monitoring systems allows:

- to effectively implement the tasks of complex control on the territory of penitentiary institutions;

- to prevent cruel treatment of prisoners by correctional institutions' staff;

- to promptly respond to emergency situations and thus ensure security within the prison.

This aspect, of course, should be taken into account and, if possible, (taking into account the development of the national scientific and technical base and its implementation in the field of law enforcement) implemented in the framework of ensuring safety in correctional institutions.

It should be noted that according to Article 83 of the Penal Code of the Russian Federation, the administration of correctional institutions has the right to use audio-visual, electronic and other technical means of control and supervision in order to prevent escapes and other crimes, violations of the order of serving a sentence, and is obliged to notify convicts on receipt of the use of technical means of control and supervision.

According to the authors of this article, taking into account the importance of technical means for ensuring penitentiary security, it should not be a question of the right, but a duty to use such means, at the same time, in addition to the designated purposes of their application, it is also necessary to indicate the purpose of ensuring the personal safety of convicts and correctional institutions' staff. It is important to emphasize that the list and procedure for the use of technical means of control and supervision should be provided for by legal acts. In this regard, it is necessary to make appropriate adjustments to Article 83 of the Penal Code of the Russian Federation.

As a matter of discussion, we note a number of topical issues of ensuring internal and external aspects of prison security.

\section{Peculiarities of penitentiary institutions functioning and ensuring security in them in emergency situations}

As reasonably noted in the special literature, these features include: establishment of a special legal regime; creation of temporary structural entities; creation of a temporary management and communication system; the use of special tactics (including special operations, the involvement of significant forces and resources of Internal Affairs and internal troops, as well as other law enforcement agencies, the use of special tools and weapons). In this regard, it is appropriate to cite foreign 
experience, including neighboring countries. For example, in correctional institutions of the Republic of Belarus, when a special status regime is introduced, visits and other contacts of convicts with the outside world may be restricted by the decision of the head of the institution, at the same time, under this regime, prisoners, who organize or provoke group illegal actions, are isolated within this institution or transferred to another one (Glushkov, A. I. 2013, pp. 28-30).

It should be noted that in foreign penitentiary practice, rather strict measures are applied to prisoners who violate the security of a penitentiary institution. So, in the UK, prisoners who participated in mass riots, disobedience, hostage-taking and attacks on administration staff in places of detention are transferred to a strict isolation prison; when such actions are committed in prison, they are placed in security category «A» cells (at the same time, they are deprived of their personal allowance and are subject to the strictest control: weekly searches are carried out both in person and in the cells where they are held.) (Coyle, A. 1994, p. 96).

\section{Private prisons}

The first version of a private closed-type prison was tested in the United States in the 1980s. Currently, private prisons are available in 27 States and are operated by 20 private companies; their capacity is $4.4 \%$ of the place limit of all American prisons (Shamsunov, S. Kh. 2016, pp. 25-28). Their positive aspects include the ability to provide prisoners with more fair, safe, humane and constructive living conditions, reducing the burden on the state for the maintenance of the prison system, and simultaneously resolving issues with the employment of prisoners (at the same time, the economic activities of private prisons make a real contribution to the national economy), improving the relationship between convicts and staff; on the other hand there is a lack of experience among the staff of such institutions in work with a contingent of convicts, in addition, with the privatization of prisons attributed the rise in the number of inmates (and therefore increasing the cost of maintenance, as well as overcrowding in prisons), abuse of forced labor in prison. It should be noted that the model of private penitentiary institutions (with various modifications) is becoming widespread in a number of foreign countries, while some countries (for example, Germany) have begun to stop privatizing prisons (Gulina, O. R. 2012). The Russian special literature suggests the possibility of gradual use of foreign experience in this area in Russia and, at the first stage (as part of an experiment), to think through and legislate a project to attract private Russian investors to the Penal system to participate in the construction, reconstruction and maintenance of pre-trial detention facilities, providing them with various preferential tax conditions (Shamsunov, S. Kh. 2016, p. 28).

As it seems to the authors, the question of introducing a model of a private penitentiary institution in the Penal system of Russia, taking into account it's positive and negative aspects, as well as taking into account the current conditions for the functioning and development of this system, it requires very careful study with involvement of a wide range of authoritative domestic experts in the field of penal law and related fields of scientific knowledge, as well as practitioners.

In any case, its introduction may be, first, gradual (from individual pilot projects, provided that they not only bring economic benefits to the state, but also comply with all relevant requirements established by legislation and other regulatory legal acts for the organization and functioning of a correctional institution (including security issues), to the possible practice expansion of such institutions creation), and secondly, formalized by law.

\section{The external side of prison security}

Describing the external aspect of penitentiary security and foreign experience in this regard, we will outline some institutions and measures used in foreign practice, some 
of which have prospects for adaptation to the modern Penal system of Russia.

First, a system of social control exists and is developing dynamically abroad for persons released from correctional institutions, especially those who are at risk of recidivism (Veldhuis, T. M. 2015). In this regard, probation should be viewed positively (as a form of social control and supervision), the services created within it and other structures that perform the function of supervision of parolees, as well as the functions of resocialization and adaptation. For example, in the United States, more than half of those, who are registered in law enforcement authorities, are under the supervision of the probation service (Kvashis, V. E. \& Vavilova, L. V. 1996, pp. 98-99). It is also necessary to pay attention to the peculiarities of post-penitentiary supervision in relation to certain categories of persons who have served their sentence (taking into account the nature of the committed crime). In England, there is strict supervision of those who have been convicted of sexual offences (Smirnov, G. G. 2004, p. 38).

Second, certain foreign countries provide for criminal legal instruments that apply to persons who have committed especially grave crime and have served prison sentences. In particular, we speak about the so-called preventive arrests (Sicherheitsverwahrung) applied within the German prison system to persons convicted for especially grave crime of a violent nature (Gulina, O. R. 2012, pp. 136-142). At the same time, it is necessary to pay attention to the reform of this institution, including under the influence of decisions of the European court of human rights (Reform der Sicherungsverwahrung. Bund und Landern konnen sich nicht einigen 2011). In general, it seems to the authors that this institution raises questions in terms of its legitimacy.

The current legislation of the Russian Federation provides for administrative supervision of persons released from prison (Federal law of 06.04.2011), the period of administrative supervision for committing a grave or especially grave crimes, and also at relapse of crimes is established from one year to three years, but not exceeding the period established by the legislation of the Russian Federation for repayment of a criminal record (this refers to Article 86 of the Criminal Code of the Russian Federation). In this regard, the domestic approach is more in line with the general law principle of legality. At the same time, it is clear that this statement does not deny the possibility to improve directly the forms of administrative supervision in order to prevent repeat offenders from committing new crimes and other offenses. The effectiveness of administrative supervision can be achieved if systematic monitoring is carried out for the supervised persons. In addition, an important role is played by an innovative component, namely, the creation of electronic records of supervised persons and access to it by all law enforcement agencies. And in this regard, the importance of advanced foreign experience and its use seems obvious.

Third, there is a tendency to increase the role of the victim of a crime in solving the issue of parole (Brusnitsyn, L. 2013, pp. 89-95). In particular, in the UK, the Parole Service is required to consult with victims of sexual and violent crimes about the possibility of criminal's early release, in this case, if it is used, in order to ensure the safety of the victim, the released person may be restricted to places of residence, work and movement (Kvashis, V.E. \& Vavilova, L. V. 1996, pp. 46-48). In the United States, a decision on parole from prison institutions is currently made by special Commissions that privately request the opinion of victims about the possibility of this act, and the victim has the right to be heard by the Commission (Kvashis, V .E. \& Vavilova, L. V. 1996, p. 57). A similar procedure applies in Canada.

In the special literature, including the analysis of recommended international legal documents, a positive assessment of this practice is expressed and a recommendation is formulated about its use in Russia, taking into account the security (personal, family members 
and close people) from the threats of the person who committed the crime (Brusnitsyn, L. 2013, pp. 89-95), the authors generally share this approach.

\section{Conclusions}

The research conducted on the basis of a comparative legal method and involving other methods of scientific knowledge has a significant novelty, since it attempts to scientifically substantiate the parameters of advanced foreign experience use in ensuring penitentiary security in the modern Penal system of Russia. The research is based on the idea that the parameters of foreign experience use should be correlated with the type of domestic legal system and the needs to reform the Penal system of Russia, taking into account the adopted political course on humanization of penitentiary activities. At the same time, penitentiary security is considered as a complex, integral phenomenon that includes the internal and external sides that are interconnected.

According to this vision, as a result of the comparison of the basic characteristics of the penitentiary systems of a number of modern foreign States and the Penal system of Russia, the provisions of advanced foreign experience that are promising for use in domestic legislation and practice are identified, and recommendations regarding the forms of this use are formulated.

In modern conditions, one of the priorities for ensuring the internal security of penitentiary institutions that carry out sentences related to isolation from society is the differentiation of detention conditions for convicts. In this regard, on the basis of generalization of best foreign experience, the conclusion is based on the reflection in the Penal legislation of Russia (articles 78, 87 of the Penal Code of the Russian Federation) of methods of differentiation of convicts used in foreign penitentiary practice based on the conclusions of specialized centers about the level of their danger and the possibility of transferring the convicted person, whose term of imprisonment ends, in a penitentiary institution with a more «soft regime» with the simultaneous passage of appropriate adaptation and resocialization programs.

The importance of technical means for ensuring penitentiary security, confirmed by the best practice of penitentiary activities, raises the question of improving the technical equipment of correctional institutions and other institutions and bodies that execute criminal penalties, and also assumes reflection in the current Penal legislation (Article 83 of the Penal Code of the Russian Federation) of obligation of correctional institutions administration to use such means in order to ensure the personal safety of convicts and correctional staff in accordance with the procedure, established by legal acts.

The humanization of penitentiary activities does not negate the adequate response of the penitentiary system to threats posed by penitentiary crime and other factors that disrupt the activity of penitentiary institutions. In this regard, domestic practice should take into account foreign experience in the operation of penitentiary institutions in emergency situations, including the establishment of a special legal regime in the parameters of current legislation.

Assessing the foreign practice of creating private closed-type penitentiary institutions, as well as the possibility of its use in domestic practice, the authors proceed from the fact that this process can be phased, at the same time complying with all relevant requirements established by legislation and other regulatory legal acts for organization and functioning of a correctional institution (including security issues).

The development of forms of social control and supervision of persons released from penitentiary institutions (especially recidivist) has prospects in Russia in the parameters provided for by the Federal law on administrative supervision of persons released from prison (2011). At the same time, 
the effectiveness of work in administrative supervision implementation can be ensured, if systematic monitoring is carried out for supervised persons, with the introduction of electronic records of supervised persons and ensuring access to it for all law enforcement agencies, using best foreign experience.

The authors share the approach found in foreign practice and reflected in the special literature, according to which it is necessary to involve the victim in the decision on parole more fully, taking into account the safety of the victim (his family and close people).

\section{References}

Coyle, A. 1994, The prisons we deserve, Harper Collins Publishers. London.

Dewey, J. 1938, 'Experience and Education', in The later works of J. Dewey, vol. 13, Carbondale.

Aebi, M. F., Burkhardt, C., Hacin, R. \& Tiago, M. M. 2016, 'A Comparative Perspective of Imprisonment Trends in Slovenia and Europe from 2005 to 2014', Revija za kriminalistiko in kriminologijo, iss. 4, pp. 430-442.

Reform der Sicherungsverwahrung. Bund und Landern konnen sich nicht einigen 2011, Stern-Magazin, 16 August.

Tonry, M. 2001, 'Symbol, Substance, and Severity in Western Penal Policies', Punishment and Society-international Journal of Penology, vol. 3.

Veldhuis, T. M. 2015, Reintegrating Violent Extremist Offenders: Policy Questions and Lessons Learned. Program on Extremism, Washington.

Kilpatrick, W. H. 1921, 'Dangers and Difficulties of the Project Method and How to Overcome Them: Introductory Statement and Definition of Terms', Teachers College Record, vol. 22, iss. 4.

Alekseev, V. I. 2010, 'Pennsylvania and Oborne convict systems: aspect of cirrelation (1860-1917)', Law practice, iss. 4, pp. 46-48.

Babaev, M. M. \& Rakhmanova, E. N. 2003, Human rights and criminological security, Moscow.
Bagreeva, E. G. 2012, 'On the organization of penitentiary systems in international practice', Penal system: law, economy, management, iss. 5, pp. 21-24.

Bakhin, S. V. 2003, Cooperation of States on convergence of national legal norms (unification and harmonization of law): PhD thesis (Law), St. Petersburg.

Belyaev, N. A. 1963, Goals of punishment and means of achieving them in correctional labor institutions, Leningrad.

Borsuchenko, S. 2016, 'Penal system: concept and content', EG-Lawyer, iss. 41, p. 2.

Brusnitsyn, L. 2013, 'About the rights of the victim at the stage of sentence execution', Criminal law, iss. 6, pp. 89-96.

Bukalerova, L. A. \& Minyazeva, T. F. 2013, 'Serving a prison sentence: the experience of the Russian Federation and Norway', Administrative and municipal law, iss. 3 , pp. 280-283.

Bykov, A. V. 2017, 'Penitentiary systems of modern democratic States: comparative legal analysis', in III International penitentiary forum "Crime, punishment, correction» (for the 20th anniversary of the entry into force of the Penal Code of the Russian Federation): a collection of speeches and reports of participants (Ryazan, November 21-23, 2017), in 8 vols, vol. 1, Proceedings of the plenary session, pp. 57-61, Academy of the FPS of Russia, Ryazan.

Bykov, A. V. \& Kaluzhina, M. A. 2015, 'Security in penal institutions of the USA', Penal system: law, economy, management, iss. 6 , pp. 28-32.

Val'ter, E. 2008, 'Basic principles of the modern system of punishments execution: the view of the head of the institution', Bulletin of the Institute: crime, punishment, correction, iss. 2, pp. 46-50.

Verren, A. 2004, 'Execution of punishment and application of criminal law measures in Switzerland for adult offenders', Actual problems of penitentiary science and practice: materials of the International scientific and practical conference, part $1, \mathrm{pp} .56, \mathrm{SRI}$ of the Ministry of justice of Russia, Moscow. 
Garmash, A., Anosov, M. \& Muzaleva L. 2012, 'The resocialisation of former prisoners: experience of foreign countries', EG-Lawyer, iss. 32 , pp. $24-28$.

Glushkov, A. I. 2013, 'Foreign experience in regulating the activities of the Penal system's institutions in emergency situations', Public and private international law, iss. 3, pp. 28-30.

Golodov, P. V. \& Spasennikov, B. A. 2015, 'Analysis of foreign experience in penitentiary activities', Penal system: law, economy, management, iss. 5, pp. 10-14.

Gorban', D. V. 2016, 'Progressive system of execution and serving of public labor', Current problems of Russian law, iss. 4, pp. 176-183.

Gorshenkov, G. G. 2009, Anti-crime security of the person: PhD thesis (Law), Stavropol.

Gulina, O. R. 2012, 'Penitentiary system of the Federal Republic of Germany in modern conditions', Russian legal journal, iss. 4, pp. 136-142.

Degtyareva, O. L. 2015, 'National features of the growth and decrease in the level of repeat crime among persons sentenced to punishments and measures of a criminal nature that are not related to the isolation of convicts from society, in the general structure of crimes committed on the territory of the country', Penal system: law, economy, management, iss. 1 , pp. 3-6.

Ivannikov, I. A. 2013, 'Comparative method in law: history and modernity', History of state and law, iss. 9, pp. 35-38.

Kvashis, V. 2005, 'Crime in the United States: the reality of positive changes or «temporary exclusion»?', Criminal law, iss. 5, pp. 97-100.

Kvashis, V. E. \& Vavilova, L. V. 1996, Foreign legislation and practice for crime protection of victims, Moscow.

Kovalev, O. G. \& Sheremet'eva, M. V. 2013, 'The penitentiary system of the USA: features of the organization and current trends', Penal system: law, economy, management, iss. 4, pp. 19-22.

Coyle, A. 2002, A human rights approach to prison management. Handbook for prison staff, International centre for prison research, London.

Koski, M. \& Druzhiniskaya, O. V. 2015, 'Organization of prisons in Finland after the reform in 2006', Bulletin of the Institute: crime, punishment, correction, iss. 3(31), pp. 90-96.

Kraynova, N. 2002, 'Resocialization of convicts. Foreign experience', Penal law, iss. 2, pp. 83-84.

Kudryavtsev, A. V. 2013, 'Operational and investigative activity as a means of reducing the criminality of the penal relations', Penal system: law, economy, management, iss. 5, pp. 20-23.

Kutakov, N. N. 2014, Organization and legal basis for ensuring the safety of correctional staff of the Federal penitentiary service of Russia: PhD thesis (Law), Ryazan.

Kurkina, I. N. 2013, 'International practice of execution of criminal penalties', in Criminal and penal policy at the present stage of society and the state development: domestic and foreign experience: materials of the International scientific and practical conference, Vladimir, November 29-30, 2012, pp. 380, Vladimir law Institute of the FPS of Russia, Vladimir.

Lelyukh, V. F. 2006, The Russian penal system: social problems of reformation: $P h D$ thesis (Sociology), Kemerovo.

Gorazd, M. \& Druzhininskaya, O. V. 2016, 'Current problems of penitentiary practice in Slovenia related to the prison occupancy limit', Bulletin of the Institute: crime, punishment, correction, iss. 36, pp. 64-67.

Minyazeva, T. F. \& Bukalerova, L. A. 2013, 'Deprivation of liberty in modern Russian and Norwegian criminal law', Bulletin of the Institute: crime, punishment, correction, iss. $3(23)$, pp. 86-89.

Nikolyuk, V. V. \& Terekyan, V. A. 2015, 'Does the victim have the right to appeal the court decision on parole of the convicted person from serving sentence?', Criminal law, iss. 3, pp. 106-111.

Pavlenko, A. A. 2015, 'To the question of possibility of using foreign experience of means 
for regime ensuring in institutions of the Penal system', Penal law, iss. 1, pp. 104-110.

Pertli, L. F., Fumm, A. M., Zheleznaya, Yu. Yu. \& Borisova, T. V. 2012, The procedure and conditions of serving sentences: comparative legal analysis of the European legislation, Moscow.

Poznyshev, S. V. 1915, Prison studies essays, Moscow.

Poznyshev, S. V. 1923, Fundamentals of penitentiary science, Moscow

Radochina, T. N. 2014, 'State institutions and legal systems', Law and policy, iss. 1, pp. 57-63.

Romashov, R. A. \& Tonkov, E. N. 2014, Prison as a "City of the earth», St. Petersburg.

Sakheym, E. 2006, 'Basic training for correctional institutions in Norway: organizational structure and directions', in Professional training for penitentiary institutions in Russia and abroad: problems and prospects, pp. 33-34, Vologda.

Seliverstov, V. I. 2000, Russian Penal law, Moscow.

Serebrennikova, A. V. 2013, 'Penal law in Bavaria', Bulletin of the Institute: crime, punishment, correction, iss. 4(24), pp. 74-78.

Smirnov, G. G. 2004, Criminological study on crime prevention: content, development, implementation, A. I. Alekseev (ed.), Ural University, Yekaterinburg.

Smirnov, L. B. 2007, The Penal system of Russia: theoretical, legal and organizational foundations, St. Petersburg.

Teplyashin, P. V. 2016, 'Modern Penal analysis of the Iberian type of European penitentiary systems', Modern law, iss. 4, pp. 113-120.

Ter-Akopov, A. A. 1998, Human security (theoretical foundations of the social and legal concept), Moscow.

Timofeeva, E. A. 2017, 'Private prisons: the possibility of integration of foreign experience in the activity of the Penal system', in III International penitentiary forum «Crime, punishment, correction» (for the 20th anniversary of the entry into force of the Criminal
Executive code of the Russian Federation): a collection of speeches and reports of participants (Ryazan, November 21-23, 2017), in 8 vols, vol. 2, Materials of the International scientific and practical conference «Improving the norms of criminal and penal enforcement legislation", pp. 102-108, Academy of the FPS of Russia, Ryazan.

Timofeeva, E. A. \& Motin, O. A. 2014, 'On the issue of foreign practice of using the electronic monitoring system for controlled persons', Bulletin of the Institute: crime, punishment, correction, iss. 4(28), pp. 88-94.

Tokhova, E. A. 2009, 'Foreign experience of social and legal control over persons released from correctional institutions', Penal system: law, economy, management, iss. 4 , pp. 198-201.

Useev, R. Z. 2015, 'Does the Penal system need a security paradigm?', Penal law, iss. $3(21)$, pp. 56-61.

Fumm, A. M. 2011, 'English progressive prison system: history and modernity', Bulletin of the Institute: crime, punishment, correction, iss. 4(16), pp. 68-72.

Chornyy, V. N. 1996, Security of convicts in prisons: PhD thesis (Law), Ryazan.

Shalakhin, I. V. 2011, Theory and methodology of studying and limiting (preventing) crime, ensuring criminological security of the individual, Moscow.

Shamsunov, S. Kh. 2016, 'Private prisons in the world: do modern Russia need them?', Penal system: law, economy, management, iss. 3 , pp. $25-28$.

Shmid, M. \& Ogrokhina, E. A. 2013, 'About the main features of the system of punishments execution and compulsory measures in Switzerland', Bulletin of the Institute: crime, punishment, correction, iss. 4(24), pp. $78-83$.

Shumilov, V. M. 2013, The legal system of the United States, Moscow.

Yakovlev, K. L., Yakovleva, E. I. \& Yakovleva, O. N. 2011, State-legal basis for the organization of law enforcement agencies in foreign countries, Moscow. 


\section{Библиографический список}

Coyle, A. 1994, The prisons we deserve, Harper Collins Publishers. London.

Dewey, J. 1938, 'Experience and Education', in The later works of J. Dewey, vol. 13, Carbondale.

Aebi, M. F., Burkhardt, C., Hacin, R. \& Tiago, M. M. 2016,' A Comparative Perspective of Imprisonment Trends in Slovenia and Europe from 2005 to 2014', Revija za kriminalistiko in kriminologijo, iss. 4, pp. 430-442.

Reform der Sicherungsverwahrung. Bund und Landern konnen sich nicht einigen 2011, Stern-Magazin, 16 August.

Tonry, M. 2001, 'Symbol, Substance, and Severity in Western Penal Policies', Punishment and Society-international Journal of Penology, vol. 3.

Veldhuis, T. M. 2015, Reintegrating Violent Extremist Offenders: Policy Questions and Lessons Learned. Program on Extremism, Washington.

Kilpatrick, W. H. 1921, 'Dangers and Difficulties of the Project Method and How to Overcome Them: Introductory Statement and Definition of Terms', Teachers College Record, vol. 22, iss. 4.

Алексеев В.И. Пенсильванская и оборнская системы содержания осужденных: аспект соотношения (1860-1917 гг.) // Адвокатская практика. 2010. № 4. С. 46-48.

Бабаев М. М., Рахманова Е. Н. Права человека и криминологическая безопасность. М., 2003. 153 c.

Багреева Е. Г. Об организации пенитенциарных систем в международной практике // Уголовно-исполнительная система: право, экономика управление. 2012. № 5. C. 21-24.

Бахин С. В. Сотрудничество государств по сближению национальных правовых норм (унификация и гармонизация права) : автореф. дис. ... д-ра юрид. наук. СПб., 2003. 46 c.

Беляев Н. А. Цели наказания и средства их достижения в исправительно-трудовых учреждениях. Л., 1963. 186 с.
Борсученко С. Уголовно-исполнительная система: понятие и содержание // ЭЖЮрист. 2016. № 41. С. 2.

Брусницын Л. О правах потерпевшего в стадии исполнения приговора // Уголовное право. 2013. № 6. С. 89-96.

Букалерова Л. А., Минязева Т. Ф. Отбывание лишения свободы: опыт Российской Федерации и Норвегии // Административное и муниципальное право. 2013. № 3. C. 280-283.

Быков А. В. Пенитенциарные системы современных демократических государств: сравнительно-правовой анализ // III Международный пенитенциарный форум «Преступление, наказание, исправление» (к 20-летию вступления в силу Уголовноисполнительного кодекса Российской Федерации) : сб. тез. выступ. и докл. участников (г. Рязань, 21-23 нояб. 2017 г.) : в 8 т. Рязань : Академия ФСИН России, 2017. Т. 1: Материалы пленарного заседания. С. 57-61.

Быков А. В., Калужина М. А. Обеспечение безопасности в пенитенциарных учреждениях США // Уголовно-исполнительная система: право, экономика управление. 2015. № 6. C. 28-32.

Вальтер Е. Основные принципы современной системы исполнения наказаний: взгляд руководителя учреждения // Вестник института: преступление, наказание, исправление. 2008. № 2. С. 46-50.

Веррен А. Исполнение наказания и применение уголовно-правовых мер в Швейцарии в отношении взрослых правонарушителей // Актуальные проблемы пенитенциарной науки и практики : материалы Междунар. науч.-практ. конф. М. : НИИ Минюста России, 2004. Ч. 1. С. 56.

Гармаш А., Аносов М., Музалева Л. Ресоциализация бывших заключенных: опыт зарубежных стран // ЭЖ-Юрист. 2012. № 32. C. 24-28.

Глушков А. И. Зарубежный опыт регламентации деятельности учреждений уголовно-исполнительной системы в условиях чрезвычайных ситуаций // Международ- 
ное публичное и частное право. 2013. № 3. C. 28-30.

Голодов П. В., Спасенников Б. А. Анализ зарубежного опыта пенитенциарной деятельности // Уголовно-исполнительная система: право, экономика управление. 2015. № 5. C. 10-14.

Горбань Д. В. Прогрессивная система исполнения и отбывания исправительных работ // Актуальные проблемы российского права. 2016. № 4. С. 176-183.

Горшенков Г. Г. Антикриминальная безопасность личности : автореф. дис. ... д-ра юрид. наук. Ставрополь, 2009. 58 с.

Гулина О. Р. Пенитенциарная система Федеративной Республики Германия в современных условиях // Российский юридический журнал. 2012. № 4. С. 136-142.

Дегтярева О. Л. Общегосударственные особенности роста и снижения уровня повторной преступности среди лиц, осужденных к наказаниям и мерам уголовно-правового характера, не связанным с изоляцией осужденных от общества, в общей структуре преступлений, совершаемых на территории страны // Уголовно-исполнительная система: право, экономика управление. 2015. № 1. C. 3-6.

Иванников И. А. Сравнительный метод в правоведении: история и современность // История государства и права. 2013. № 9. C. 35-38.

Квашис В. Преступность в США: реальность позитивных изменений или «временное исключение»? // Уголовное право. 2005. № 5. С. 97-100.

Квашис В .Е., Вавилова Л. В. Зарубежное законодательство и практика защиты жертв преступлений. М., 1996. 128 с.

Ковалев О. Г., Шереметьева М. В. Пенитенциарная система США: особенности организации и современные тенденции // Уголовно-исполнительная система: право, экономика управление. 2013. № 4. С. 19-22.

Койл Э. Подход к управлению тюрьмой с позиции прав человека. Пособие для тюремного персонала. Лондон : Международ- ный центр тюремных исследований, 2002. $156 \mathrm{c}$.

Коски М., Дружиниская О. В. Организация тюрем в Финляндии после реформы 2006 г. // Вестник института: преступление, наказание, исправление. 2015. № 3(31). C. 90-96.

Крайнова Н. Ресоциализация осужденных. Зарубежный опыт // Уголовно-исполнительное право. 2002. № 2. С. 83-84.

Кудрявцев А. В. Оперативно-розыскная деятельность как средство снижения криминогенности уголовно-исполнительных правоотношений // Уголовно-исполнительная система: право, экономика управление. 2013. № 5. C. 20-23.

Кутаков Н. Н. Организация и правовые основы обеспечения безопасности персонала исправительных учреждений ФСИН России : автореф. дис. ... канд. юрид. наук. Ryazan, 2014. 22 c.

Куркина И. Н. Международная практика исполнения уголовных наказаний // Уголовная и уголовно-исполнительная политика на современном этапе развития общества и государства: отечественный и зарубежный опыт : материалы Междунар. науч.-практ. конф., Владимир, 29-30 нояб. 2012 г. Владимир : Владимир юридический институт ФСИН России, 2013. С. 380.

Лелюх В. Ф. Российская уголовно-исполнительная система: социальные проблемы реформирования : автореф. дис. ... д-ра социол. наук. Кемерово, 2006. 52 с.

Горазд М., Дружининская О. В. Актуальные проблемы пенитенциарной практики в Словении, связанные с лимитом наполнения тюрем // Вестник института: преступление, наказание, исправление. 2016. № 36. C. 64-67.

Минязева Т. Ф., Букалерова Л. А. Лишение свободы в современном российском и норвежском уголовном законодательстве // Вестник института: преступление, наказание, исправление. 2013. № 3(23). С. 86-89.

Николюк В. В., Терекян В. А. Вправе ли потерпевший обжаловать судебное поста- 
новление об условно-досрочном освобождении осужденного от отбывания наказания? // Уголовное право. 2015. № 3. C. 106-111.

Павленко А. А. К вопросу о возможности использования зарубежного опыта средств обеспечения режима в учреждениях уголовно-исполнительной системы // Уголовно-исполнительное право. 2015. № 1. C. 104-110.

Пертли Л. Ф., Фумм А. М., ЖелезнаяЮ. Ю., Борисова Т. В. Порядок и условия отбывания лишения свободы: сравнительно-правовой анализ европейского законодательства. М., 2012. 100 с.

Познышев С. В. Очерки тюрьмоведения. М., 1915. 302 C.

Познышев С. В. Основы пенитенциарной науки. М., 1923. 843 с.

Радочина Т. Н. Государственные институты и правовые системы // Право и политика. 2014. № 1. С. 57-63.

Ромашов Р. А., Тонков Е. Н. Тюрьма как «Град земной». СПб., 2014. 656 с.

Сахейм Э. Базовая подготовка кадров для исправительных учреждений Норвегии: организационная структура и направления // Профессиональная подготовка кадров для пенитенциарных учреждений в России и за рубежом: проблемы и перспективы. Вологда, 2006. С. 33-34.

Селиверстов В. И. Уголовно-исполнительное право России : учебник. М., 2000. $704 \mathrm{c}$.

Серебренникова А. В. Уголовно-исполнительное законодательство Баварии // Вестник института: преступление, наказание, исправление. 2013. № 4(24). С. 74-78.

Смирнов Г. Г. Криминологическое учение о предупреждении преступности: содержание, развитие, реализация / под ред. А. И. Алексеева. Екатеринбург : Уральский университет, 2004. 190 с.

Смирнов Л. Б. Уголовно-исполнительная система России: теоретические, правовые и организационные основы : монография. СПб., 2007. 228 с.
Тепляшин П. В. Современный уголовноисполнительный анализ иберийского типа европейских пенитенциарных систем // Современное право. 2016. № 4. C. $113-120$.

Тер-Акопов А. А. Безопасность человека (теоретические основы социально-правовой концепции). М., 1998. 194 с.

Тимофреева Е. А. Частные тюрьмы: возможности интеграции зарубежного опыта в деятельность уголовно-исполнительной системы // III Международный пенитенциарный форум «Преступление, наказание, исправление» (к 20-летию вступления в силу Уголовно-исполнительного кодекса Российской Федерации) : сб. тез. выступ. и докл. участников (г. Рязань, 21-23 нояб. 2017 г.) : в 8 т. Рязань : Академия ФСИН России, 2017. Т. 2: Материалы Международной научно-практической конференции «Совершенствование норм уголовного и уголовно-исполнительного законодательства». С. 102-108.

Тимофреева Е. А., Мотин О. А. К вопросу о зарубежной практике применения системы электронного мониторинга подконтрольных лиц // Вестник института: преступление, наказание, исправление. 2014. № 4(28). C. 88-94.

Тохова Е. А. Зарубежный опыт социально-правового контроля за лицами, освобожденными из исправительных учреждений // Уголовно-исполнительная система: право, экономика управление. 2009. № 4. C. $198-201$.

Усеев Р. 3. Нужна ли уголовно-исполнительной системе парадигма безопасности // Уголовно-исполнительное право. 2015. № 3(21). С. 56-61.

Фумм А. М. Английская прогрессивная система тюремного заключения: история и современность // Вестник института: преступление, наказание, исправление. 2011. № 4(16). С. 68-72.

Чорный В. Н. Безопасность осужденных в условиях лишения свободы : автореф. дис. ... канд. юрид. наук. Ryazan, 1996. 22 с. 
International penitentiary journal, 2019, vol. 1(1-3), iss. 3

Шалахин И. В. Теория и методология изучения и ограничения (предупреждения) преступности, обеспечения криминологической безопасности личности. М., 2011. $188 \mathrm{c}$.

Шамсунов С. Х. Частные тюрьмы в мире: нужны ли они современной России? // Уголовно-исполнительная система: право, экономика управление. 2016. № 3. С. 25-28.

Шмид М., Огрохина Е. А. Об основных особенностях системы исполнения на- казаний и принудительных мер Швейцарии // Вестник института: преступление, наказание, исправление. 2013. № 4(24). C. $78-83$.

Шумилов В. М. Правовая система США : учеб. пособие. М., 2013. 149 с.

Яковлев К. Л., Яковлева Е. И., Яковлева О. Н. Государственно-правовые основы организации правоохранительных органов зарубежных стран : монография. М., 2011. $160 \mathrm{c}$. 